\title{
Perlindungan Hukum Terhadap Protokol Notaris Dari Notaris Yang Meninggal Dunia Di Kabupaten Temanggung
}

\author{
Angie Athalia Kusuma \\ Program Studi Kenotariatan Fakultas Hukum Universitas Islam Indonesia Yogyakarta Indonesia \\ Jln. Cik Di Tiro No. 1 Yogyakarta Indonesia \\ angieathalia12@gmail.com
}

\begin{tabular}{ll}
\hline Key Word: & Abstract \\
$\begin{array}{l}\text { Legal protection; } \\
\text { notary protocol; }\end{array}$ & This study discusses first, the legal protection of the Notary Protocol for a Notary \\
notary supervisory & Regional Supervisory Council (MPD) in Temanggung Regency in resolving the \\
council & Notary Protocol issue. The type of research used is empirical with a sociological \\
& juridical approach and qualitative data analysis. The result of this study conclude, \\
& first, that the legal protection of the Notary Protocol in Temanggung Regency has \\
& not been fully implemented in accordance with Article 16 letter b of the UUJN. In \\
& the first case there is still a Notary Protocol that has been lost due to the actions of \\
& uncooperative heirs and in the second case the Notary Protocol has landed on the \\
& right hands because the Notary who gave the Notary Protocol had realized that they \\
& would soon retire and acknowledged the importance of the Notary Protocol as state \\
& archives which must be protected and delegated to the right person. The second \\
& result showed that Temanggung district MPD has played an active role in \\
& providing guidance and supervision to the Notary but the recipient of the Notary \\
& Protocol cannot cooperate well hence the role of MPD is not optimalized.
\end{tabular}

Kata-kata Kunci:
Majelis pengawas
notaris;
perlindungan
hukum; protokol
notaris

\section{Abstrak}

Penelitian ini membahas tentang pertama, perlindungan hukum terhadap Protokol Notaris dari Notaris yang meninggal dunia di Kabupaten Temanggung; dan kedua, peran Majelis Pengawas Daerah (MPD) Notaris di notaris Kabupaten Temanggung menyelesaikan masalah Protokol Notaris. Jenis penelitian yang digunakan adalah empiris dengan pendekatan yuridis sosiologis serta analisa data secara kualitatif. Hasil penelitian ini menyimpulkan, pertama, perlindungan hukum terhadap protokol Notaris di Kabupaten Temanggung belum sepenuhnya berjalan sesuai dengan Pasal 16 huruf b UUJN. Pada kasus pertama masih ada protokol Notaris yang hilang jejaknya dikarenakan ulah ahli waris yang tidak kooperatif dan pada kasus kedua protokol Notaris sampai ditangan yang tepat karena Notaris pemberi protokol Notaris menyadari bahwa dirinya akan pensiun dan Notaris pemberi protokol Notaris menyadari pentingnya protokol Notaris sebagai arsip milik Negara yang harus dilindungi dan dilimpahkan kepada orang yang tepat. Kedua, MPD abupaten Temanggung sudah berperan aktif dalam melakukan pembinaan dan pengawasan kepada Notaris tetapi Notaris penerima protokol Notaris tidak dapat bekerjasama sehingga peran MPD menjadi tidak optimal.

\section{Pendahuluan}

UUJN mempunyai visi mewujudkan Negara hukum yang dapat menjamin kepastian, ketertiban dan perlindungan hukum yang berintikan pada kebenaran dan keadilan serta mempunyai misi memberikan perlindungan hukum kepada masyarakat, 
memberikan perlindungan dan jaminan hukum kepada Notaris, dan memberikan jaminan terhadap validitas dari akta Notaris sebagai alat bukti yang sempurna.

Menurut Abdul Ghofur Anshori, pejabat umum dalam hal ini Notaris harus sedapat mungkin menjalankan tugas jabatannya dengan baik yaitu

1. Notaris dituntut melakukan pembuatan akta dengan baik dan benar sesuai dengan ketentuan umum. Artinya akta yang dibuat harus memenuhi kehendak hukum dan permintaan para pihak yang berkepentingan.

2. Berdampak positif, artinya akta Notaris itu mempunyai kekuatan pembuktian yang sempurna. Pada Notaris melekat tanggung jawab atas perbuatannya dalam membuat suatu akta otentik. ${ }^{1}$

Notaris dalam menjalankan tugas dan jabatannya wajib berpedoman secara normatif kepada aturan hukum yang berkaitan dengan segala tindakan yang akan diambil untuk kemudian dituangkan dalam akta. ${ }^{2}$ Berdasarkan ketentuan Pasal 1 angka (7) UUJN dijelaskan bahwa Akta Notaris yang selanjutnya disebut akta adalah akta otentik yang dibuat oleh atau di hadapan Notaris menurut bentuk dan tata cara yang ditetapkan Undang-Undang ini. Dari Pasal tersebut dapat dicermati bahwa pada dasarnya terdapat dua jenis akta yang menjadi ruang lingkup dari produk hukum Notaris yaitu Akta Relaas dan Akta Partij.

Akta Notaris yang telah dibuat baik itu berupa Akta Relaas maupun Akta Partij, kemudian ditandatangani oleh para pihak, saksi-saksi dan Notaris itu sendiri sebagai bentuk telah sempurnanya proses pembuatan akta yang kemudian akan mengikat para pihak yang menjadi bagian dari akta tersebut. Akta inilah yang kemudian disebut Minuta Akta atau Asli Akta sebagaimana diatur dalam Pasal 1 angka (8) UUJN yaitu Minuta Akta adalah asli Akta yang mencantumkan tanda tangan para penghadap, saksi dan Notaris, yang disimpan sebagai bagian dari Protokol Notaris. Bertindak berdasarkan aturan hukum yang berlaku tentunya akan memberikan kepastian hukum kepada para pihak, bahwa akta yang dibuat di hadapan atau oleh Notaris telah sesuai dengan aturan hukum yang berlaku, sehingga jika terjadi permasalahan akta Notaris tersebut dapat menjadi pedoman oleh para pihak. ${ }^{3}$

Salah satu kewajiban Notaris adalah membuat akta dalam bentuk minuta akta dan menyimpannya yang nanti dikemudian hari akan menjadi bagian dari protokol Notaris sebagaimana diatur dalam Pasal 16 ayat (1) huruf b UUJN. Protokol Notaris sangat diperlukan karena memiliki kekuatan pembuktian yang tidak hanya sebatas pada saat Notaris menjalankan jabatannya atau selagi Notaris tersebut masih hidup melainkan juga sampai dengan bahkan setelah tutup usia (meninggal). Oleh karena itu keberadaan minuta akta dapat lebih lama dari waktu masa jabatan Notaris yang membuatnya,

Pentingnya kedudukan akta otentik yang dibuat oleh Notaris mengharuskan penyimpanan minuta akta juga menjadi unsur penting yang tidak dapat diabaikan

\footnotetext{
1 Abdul Ghofur Anshori, Lembaga Kenotariatan Indonesia Perspektif Hukum dan Etika, Yogyakarta: UII Press, Yogyakarta, 2009, hlm. 90. 56.

2 R. Soesanto, Tugas, Kewajiban dan Hak-Hak Notaris, Wakil Notaris, Pradnya Paramita, Jakarta, 1982, hlm.

3 Soegondo Notodisoerjo, Hukum Notariat di Indonesia (Suatu Penjelasan), Ctk. Kedua, Raja Grafindo Persada, Jakarta, 1993, hlm. 49.
} 
karena dengan penyimpanan minuta akta yang rapi, tertib dan terjamin keamanannya dapat menyelesaikan masalah atas konflik yang terjadi dikemudian hari antara para pihak. Hal ini dikarenakan arsip yang berkaitan dapat ditemukan dengan mudah saat diperlukan.

Sebelum lahirnya UUJN, lembaga yang melaksanakan fungsi pengawasan terhadap Notaris dilakukan oleh Pengadilan Negeri setempat (Kota atau Kabupaten) di tempat kedudukan Notaris, namun sejak UUJN diundangkan, pengawasan terhadap Notaris dilakukan oleh Majelis Pengawas yang dibentuk Menteri Hukum dan Hak Asasi Manusia Republik Indonesia yang terdiri dari Majelis Pengawas Daerah (MPD), Majelis Pengawas Wilayah (MPW) dan Majelis Pengawas Pusat (MPP). ${ }^{4}$ Pasal 1 angka 6 UUJN menyatakan bahwa Majelis Pengawas adalah suatu badan yang mempunyai kewenangan dan kewajiban untuk melaksanakan pembinaan dan pengawasan terhadap Notaris. Majelis Pengawas Notaris merupakan satu-satunya instansi yang berwenang melakukan pengawasan, pemeriksaan dan menjatuhkan sanksi kepada Notaris dan setiap jenjang Majelis Pengawas mempunyai wewenang masing-masing.

UUJN tidak memberikan definisi mengenai pengawasan. Pengertian pengawasan dapat ditemukan dalam ketentuan Pasal 1 angka (8) Keputusan Menteri Kehakiman dan HAM No. M-01.HT.03.01 Tahun 2003 tentang KeNotarisan bahwa pengawasan adalah kegiatan administratif yang bersifat preventif dan represif oleh Menteri yang bertujuan untuk menjaga agar para Notaris dalam menjalankan jabatannya sesuai dengan peraturan perundang-undangan. ${ }^{5}$ Pengawasan preventif dilakukan oleh Negara sebagai pemberi wewenang yang dilimpahkan pada Menteri Hukum dan HAM. Sementara pengawasan represif dilakukan oleh Organisasi Profesi Notaris dengan acuan Kode Etik Notaris dan UUJN.

Berdasarkan ketentuan Pasal 66 ayat (1) UUJN menyatakan untuk kepentingan proses peradilan, penyidik, penuntut umum atau hakim dengan persetujuan Majelis Kehormatan Notaris berwenang (a). mengambil fotokopi Minuta Akta dan atau surat-surat yang dilekatkan pada Minuta Akta atau Protokol Notaris dalam penyimpanan Notaris. Tanggung jawab Notaris saat menjabat terkait juga dengan penyimpanan seluruh protokol Notaris yang terimanya. MPD mempunyai peranan yang sangat penting dalam pelaksanaan kewajiban Notaris terhadap protokol Notaris, termasuk di dalamnya melakukan pemeriksaan terhadap protokol Notaris secara berkala 1 kali dalam 1 tahun atau setiap waktu yang dianggap perlu serta menerima laporan dari masyarakat mengenai adanya dugaan pelanggaran Kode Etik atau pelanggaran ketentuan dalam Undang-Undang ini. ${ }^{6}$

Protokol Notaris adalah kumpulan dokumen yang merupakan arsip Negara yang harus disimpan dan dipelihara oleh Notaris. Kewajiban untuk menyimpan Protokol Notaris tidak terbatas pada penyimpanan protokol yang dibuat oleh dan/atau di hadapan Notaris itu sendiri, akan tetapi juga berlaku untuk penyimpanan protokol yang diserahkan dari Notaris itu, di mana Notaris yang menerima protokol tersebut bertugas sebagai penyimpan protokol terhadap protokol yang telah diserahkan kepadanya. UUJN

${ }^{4}$ Pasal 68 Undang-Undang Nomor 2 Tahun 2014 tentang Jabatan Notaris.

${ }^{5}$ Hartanti Sulihandri dan Nisya Rifiani, Prinsip-Prinsip Dasar Profesi Notaris, Ctk. Kesatu, Dunia Cerdas, Jakarta, 2013, hlm. 136.

${ }^{6}$ Pasal 70 huruf (b) dan (g) Undang-Undang Nomor 2 Tahun 2014 tentang Jabatan Notaris 
dalam hal ini tidak mengatur bagaimana cara penyimpanan dan juga di mana tempat penyimpanannya, yang mana tempat penyimpanan tersebut harus mudah dijangkau, aman dan dapat dikunci.

Sedemikian pentingnya kedudukan akta otentik yang dibuat oleh Notaris sehingga mengakibatkan penyimpanan minuta akta sebagai bagian dari protokol Notaris merupakan hal yang sangat penting. Dapat dibayangkan berapa luas tempat yang diperlukan untuk menyimpan protokol Notaris tersebut selain juga resiko apabila terjadi kebakaran, bencana banjir ataupun lapuk dirusak oleh serangga. Mengingat ruang lingkup tugas dan tanggung jawab Notaris sesuai ketentuan UUJN sangat luas, dalam hal ini Penulis tertarik untuk meneliti terkait tanggung jawab Notaris yang berkaitan dengan protokol Notaris dengan fakta bahwa protokol Notaris merupakan arsip Negara yang harus dipelihara dan dijaga oleh Notaris karena dapat dijadikan sebagai alat bukti yang sah dan kuat apabila suatu saat terjadi sengketa baik menyangkut isi suatu akta maupun terkait para pihak yang ada di dalamnya, yang dalam hal apabila Notaris tersebut sudah tidak lagi menjabat sebagai Notaris dikarenakan meninggal dunia ataupun karena hal lainnya yang kemudian mengakibatkan seorang Notaris harus melimpahkan arsipnya ke Notaris lain.

Belakangan muncul permasalahan yang cukup meresahkan bagi Notaris itu sendiri yaitu perihal penyimpanan Protokol Notaris baik bagi Notaris yang sudah pensiun ataupun Notaris yang meninggal dunia. Apabila ada seorang Notaris yang sudah pensiun atau meninggal dunia maka pertanyaan selanjutnya adalah mau diapakan Protokol Notaris tersebut? Lalu apabila diharuskan untuk disimpan maka di manakah seharusnya Protokol Notaris tersebut disimpan? Mengingat UUJN belum secara rinci mengatur permasalahan tersebut. Dalam UUJN Pasal 62 disebutkan bahwa penyerahan Protokol Notaris dilakukan dalam hal Notaris meninggal dunia, telah berakhir masa jabatannya, minta sendiri, tidak mampu secara rohani dan/atau jasmani untuk melaksanakan tugas jabatan sebagai Notaris secara terus-menerus lebih dari 3 tahun,diangkat menjadi pejabat Negara, pindah wilayah jabatan,diberhentikan sementara, atau diberhentikan dengan tidak hormat.

UUJN menyebutkan dalam Pasal 63 ayat (2) dalam hal terjadi sebagaimana dimaksud dalam Pasal 62 huruf a, penyerahan Protokol Notaris dilakukan oleh ahli waris Notaris kepada Notaris lain yang ditunjuk oleh MPD. Di dalam praktek kehidupan tidak selamanya ketentuan yang telah tertulis dapat berjalan sebagaimana mestinya, seperti halnya yang terjadi pada Notaris di Kabupaten Temanggung. Sebagai contoh ada 2 kasus Notaris yang meninggal dunia di kabupaten Temanggung. Kasus pertama adalah terdapat Notaris yang meninggal dunia, kemudian ahli waris dari Notaris tersebut justru mengajukan diri untuk menerima protokol Notaris dari Notaris yang meninggal dunia tersebut dikarenakan Notaris yang meninggal dunia adalah ayahnya. Kasus kedua adalah seorang Notaris yang sedang sakit parah justru menunjuk Notaris lain untuk menerima protokol Notarisnya tanpa persetujuan MPD sebelumnya. Di sini lah Penulis tertarik untuk meneliti sejauh mana perlindungan terhadap protokol Notaris di Kabupaten Temanggung dan juga apakah peran MPD sudah berjalan sebagaimana mestinya. Atas dasar itu Penulis ingin mengkaji kasus tersebut khususnya mengenai Protokol Notaris sebagai dasar penelitian. 


\section{Rumusan Masalah}

Berdasarkan latar belakang masalah di atas dapat dirumuskan dua masalah yakni, pertama, bagaimana perlindungan hukum terhadap Protokol Notaris dari Notaris yang meninggal dunia di Kabupaten Temanggung? Kedua, bagaimana peran MPD Notaris di Kabupaten Temanggung menyelesaikan masalah Protokol Notaris tersebut?

\section{Tujuan Penelitian}

Penelitian ini bertujuan untuk mengkaji dan menganalisis perlindungan hukum terhadap Protokol Notaris dari Notaris yang meninggal dunia di Kabupaten Temanggung dan peran serta tindakan MPD dalam menyelesaikan masalah Protokol Notaris dari Notaris yang meninggal dunia di Kabupaten Temanggung.

\section{Metode Penelitian}

Penelitian hukum pada prinsipnya untuk mengkonsepsikan hukum sebagai perilaku ajeg dan/atau hukum sebagai interaksi sosial. Metodelogi atau cara penelitian yang digunakan dalam penelitian ini adalah field research (penelitian lapangan) yaitu secara langsung mengadakan pengamatan untuk memperoleh informasi yang diperlukan dalam penyusunan laporan ini dengan menggunakan metode empiris, yaitu mengkaji ketentuan hukum yang berlaku dengan apa yang terjadi dalam kenyataan di lapangan.

\section{Hasil Penelitian dan Pembahasan}

\section{Perlindungan Hukum terhadap Protokol Notaris dari Notaris yang Meninggal Dunia di Kabupaten Temanggung}

Berdasarkan fakta yang terjadi di lapangan, penelitian ini menjadikan 2 contoh kasus nyata di Kabupaten Temanggung sebagai obyek penelitian. Posisi kasus yang pertama adalah dengan meninggalnya Notaris Kadarisman yang mana Beliau tidak sempat atau belum menyerahkan protokol Notarisnya kepada siapapun. Namun dikarenakan anak Beliau juga adalah seorang Notaris yang berpraktek di kabupaten Temanggung, maka sang anak yaitu Notaris Dewi Puspa yang sekaligus bertindak sebagai ahli waris memutuskan bahwa protokol Notaris dari Notaris Kadarisman akan diterimanya sendiri. Akan tetapi sampai dengan penelitian ini dilakukan, protokol Notaris tersebut belum juga diserahterimakan yang seharusnya disaksikan oleh MPD padahal Notaris Kadarisman sudah meninggal dunia 1 tahun yang lalu. Menurut narasumber, ${ }^{7}$ hal tersebut dikarenakan Notaris penerima protokol yang seharusnya adalah Notaris Dewi Puspa tidak kooperatif dalam mengurus serahterima protokol Notaris dari Notaris Kadarisman.

Hal-hal yang harus dilakukan terhadap protokol Notaris apabila seorang Notaris meninggal dunia sudah diatur dalam Pasal 63 UUJN yaitu (1) penyerahan protokol Notaris dilakukan paling lama 30 hari dengan pembuatan berita acara penyerahan

${ }^{7}$ Wawancara dengan Anita Febe Holiana, selaku Notaris \& mantan Anggota Majelis Pengawas Daerah di Kabupaten Temanggung pada Kamis, 22 Oktober 2020. 
protokol Notaris yang ditandatangani oleh yang menyerahkan dan menerima protokol Notaris. Namun ketentuan tersebut tidak berjalan sebagaimana seharusnya seperti dalam kasus Notaris Kadarisman. Protokol Notaris harus disimpan dan dipelihara dengan baik. Oleh karena itu kewajiban Notaris dalam memelihara protokol Notaris akan beralih kepada Notaris penerima protokol salah satunya pada saat seorang Notaris meninggal dunia.

Pada saat itu narasumber bertindak sebagai Anggota Majelis Pengawas Daerah. Telah disebutkan dalam Pasal 63 ayat (1) UUJN bahwa penyerahan protokol Notaris dilakukan paling lama 30 hari dengan pembuatan berita acara penyerahan protokol Notaris yang harus ditandatangani oleh ahli waris yang menyerahkan protokol Notaris dan Notaris yang menerima protokol Notaris. Namun sampai dengan tenggang waktu penyerahan protokol Notaris berakhir hal tersebut tidak juga terlaksana. Menurut narasumber pada saat meninggalnya Notaris Kadarisman, ahli waris sudah melaporkan kepada Majelis Pengawas Daerah tetapi dalam jangka waktu 30 hari ahli waris tidak juga melakukan serah terima protokol Notaris. Di sinilah dibutuhkan kesadaran atas tanggungjawab ahli waris.

Pada kasus Notaris Kadarisman, diketahui bahwa yang menerima protokol Notaris adalah ahli waris Beliau sendiri. UUJN tidak mengatur kriteria tertentu atau persyaratan khusus mengenai siapa saja yang berhak memegang protokol Notaris. Dalam UUJN hanya dijelaskan bahwa apabila seorang Notaris meninggal dunia maka penyerahan protokol Notaris dilakukan oleh ahli waris Notaris kepada Notaris lain yang ditunjuk oleh MPD. MPD pada saat itu menyetujui bahwa protokol Notaris tersebut akan diberikan kepada Notaris Dewi Puspa, karena beranggapan bahwa lebih memudahkan proses serah terima protokol Notaris dan menghemat waktu. Namun justru Notaris Dewi Puspa lalai menjalankan ketentuan Pasal 63 ayat (1) UUJN dimana sudah lebih dari 30 hari belum juga melakukan serahterima protokol Notaris dari Notaris Kadarisman dengan diketahui MPD. Hingga saat ini MPD kesulitan untuk menemui Notaris Dewi Puspa padahal berbagai usaha sudah dilakukan tetapi belum juga membuahkan hasil.

Posisi kasus yang kedua adalah dengan meninggalnya Notaris O. A. Martha Wibisono, dimana Notaris yang bersangkutan menderita sakit yang cukup serius dan disaat-saat terakhirnya Beliau sempat menitipkan atau mempasrahkan protokol Notarisnya kepada Notaris Anita Febe Holiana. Pada saat itu Notaris pemberi protokol sedang menjalani perawatan di Rumah Sakit Umum Pusat Dr. Kariadi Semarang. Melihat perkembangan kondisi kesehatannya yang tidak juga membaik, Notaris pemberi protokol menunjuk staff nya untuk menemui Notaris penerima protokol. Hal ini terjadi berulang kali sampai dengan tiga kali dimana staf dari pemberi protokol memohon kepada Notaris penerima protokol untuk mau menerima protokol Notaris dari atasannya tersebut dan mendesak untuk segera melakukan penyerahan dan menandatangani berita acara serah terima protokol Notaris.

Awal mulanya Notaris penerima protokol Notaris menolak untuk menerima protokol Notaris tersebut dengan alasan permohonan tersebut belum diketahui oleh MPD kabupaten Temanggung. Namun dikarenakan situasi yang semakin mendesak lantaran kondisi kesehatan Notaris pemberi protokol Notaris yang terus menurun, akhirnya Notaris penerima protokol Notaris berinisiatif untuk melapor kepada Ketua 
MPD yang pada saat itu. Namun demikian pada saat itu Ketua MPD berhalangan hadir dikarenakan sedang berada di luar kota. Kemudian Notaris penerima protokol Notaris meminta kepada salah satu Anggota MPD yang berada di Kabupaten Temanggung yaitu Mursidi untuk menyaksikan proses serah terima protokol tersebut.

Notaris penerima protokol Notaris dan Anggota MPD berangkat ke Rumah Sakit Umum Pusat Dr. Kariadi Semarang untuk menemui Notaris pemberi protokol Notaris yang sedang menjalani perawatan. Di sanalah terjadi penyerahan Berita Acara Serahterima Protokol Notaris O. A. Martha Wibisono yaitu pada Rabu, 14 Agustus 2019 di hadapan Mursidi selaku Anggota MPD Kedu Utara, bahwa O. A. Martha Wibisono berdasarkan S.K. Notaris Nomor: M-131-HT.03.01-Th.1986 tertanggal 26 November 1986 masa Jabatan Selaku Notaris akan berakhir, maka dengan ini menyerahkan Protokol Notaris kepada Anita Febe Holiana Notaris di kabupaten Temanggung.

Protokol Notaris adalah kumpulan dokumen yang merupakan arsip Negara yang harus disimpan dan dipelihara oleh Notaris sesuai dengan ketentuan peraturan perundang-undangan. Sebagai dokumen penting milik Negara yang berfungsi sebagai alat bukti maka sudah seharusnya protokol Notaris dijaga dengan baik. Penyimpanan protokol Notaris oleh Notaris pemegang protokol merupakan suatu upaya untuk menjaga umur yuridis akta Notaris sebagai alat bukti yang sempurna bagi para pihak atau ahli warisnya tentang segala hal yang termuat di dalam akta tersebut. Notaris meninggal dunia, tapi akta Notaris akan tetap ada yang mempunyai umur yuridis melebihi umur biologis Notaris itu sendiri. 8

Kurangnya pengaturan mengenai protokol Notaris mengakibatkan banyak kasus terjadi di mana protokol Notaris itu diterlantarkan, tidak terawat atau bahkan hilang tanpa jejak. Sebagai contoh kasus pertama yang terjadi di kabupaten Temanggung, sampai saat ini masih ada protokol Notaris yang hilang tanpa jejak. Hal tersebut dikarenakan tidak adanya serah terima protokol Notaris oleh ahli waris kepada MPD. Menurut narasumber pada kasus Notaris Kadarisman, hilangnya jejak protokol Notaris disebabkan oleh ahli warisnya. MPD kesulitan untuk menemui Notaris Dewi Puspa. Beberapa kali tim Majelis Pengawas Daerah mengirim surat teguran tidak juga dihiraukan. Beberapa kali telah membuat janji untuk bertemu di kantornya namun pada saat didatangi justru Notaris yang bersangkutan beralasan sedang ke luar kota. Setelah ditelusuri ternyata kantor tersebut sudah lama tutup dan menurut kesaksian warga sekitar bahwa bangunan yang digunakan sebagai kantor tersebut telah dikontrakan.

\section{Peran Majelis Pengawas Daerah Notaris di Kabupaten Temanggung Menyelesaikan masalah Protokol Notaris}

Majelis Pengawas Notaris adalah suatu badan yang mempunyai kewenangan dan kewajiban untuk melaksanakan pembinaan dan pengawasan terhadap Notaris. MPD adalah majelis pengawas ditingkat Kabupaten/Kota yang merupakan ujung tombak pengawasan Notaris di daerah yang mempunyai tugas dan wewenang untuk mengawasi dan melakukan pembinaan terhadap Notaris dalam melaksanakan jabatan. MPD

8 Habib Adjie, Hukum Notaris Indonesia - Tafsir Tematik. Terbadap UU No. 30 Tahun 2004 Tentang Jabatan Notaris, Refika Aditama, Bandung, 2010, hlm. 54. 
berwenang melakukan pemeriksaan terhadap protokol Notaris secara berkala 1 kali dalam 1 tahun atau setiap waktu yang dianggap perlu (Pasal 70 huruf b UUJN).

Menurut narasumber ${ }^{9}$ setelah meninggalnya Notaris Kadarisman, sampai sekarang belum ada serah terima protokol Notaris. Hal tersebut disebabkan karena ahli waris sekaligus penerima protokol Notaris belum juga menyerahkannya. Pada saat Notaris Kadarisman meninggal dunia, Notaris Dewi Puspa meminta izin kepada Ketua MPD untuk diperkenankan menerima protokol Notaris dari Notaris Kadarisman Adanya hubungan kekeluargaan diantara kedua belah pihak menjadi pertimbangan tim MPD untuk menyetujui hal tersebut. Menurut MPD setempat, protokol Notaris sebaiknya dipegang oleh seorang penerima protokol Notaris yang memiliki hubungan baik, hubungan akrab atau bahkan hubungan kekeluargaan dengan pemberi protokol Notaris.

Tidak ada penunjukan Notaris penerima protokol Notaris oleh MPD. MPD menyetujui begitu saja permohonan Notaris pemberi dan penerima protokol Notaris. Masalah yang hingga saat ini belum terpecahkan adalah menghilangnya Notaris Dewi Puspa yang merupakan penerima protokol Notaris dari Notaris Kadarisman. Narasumber berpendapat bahwa berbagai upaya telah dilakukan oleh tim MPD tetapi belum membuahkan hasil. Diketahui kini Notaris Dewi Puspa juga ikut menutup kantornya dan tidak lagi menjalankan praktek di alamat kerjanya. Tim MPD sudah melaporkan kasus ini kepada MPP tetapi belum juga mendapat respon. Narasumber berpendapat bahwa kasus seperti ini akan menjadi persoalan yang panjang sekaligus sebagai pembelajaran untuk semua pihak yang terlibat khususnya MPD.

Aspek hukum yang terkait dengan protokol Notaris belum diatur secara menyeluruh, khususnya terhadap pertanggungjawaban ahli waris Notaris yang tidak segera menyerahkan protokol Notaris yang disaksikan oleh MPD. Hal ini dapat dilihat dari belum adanya ketentuan yang secara jelas mengatur mengenai sanksi bagi ahli waris yang tidak segera menyerahkan protokol Notaris sampai batas waktu yang ditentukan oleh UUJN. Dapat dilihat bahwa peran MPD belum maksimal dalam melaksanakan kewenangannya. MPD tidak bisa bertindak apa-apa dikarenakan laporan kepada MPW juga belum ditindak lanjuti. Narasumber berpendapat bahwa hal ini disebabkan karena setiap individu yang ditunjuk sebagai bagian dari MPD memiliki kesibukan masingmasing dan juga tidak semua unsur MPD adalah seorang Notaris sehingga mereka tidak paham betul terhadap seluk beluk permasalahan yang dihadapi Notaris.

Beda hal dalam kasus meninggalnya Notaris O. A. Martha Wibisono yang mana Beliau sempat menitipkan protokol Notarisnya kepada Notaris penerima protokol yaitu Notaris Anita Febe Holiana dan setelah terjadi serah terima protokol Notaris, yang bertanggungjawab sepenuhnya untuk menjaga protokol Notaris adalah Notaris penerima protokol Notaris. Langkah-langkah yang dilakukan oleh Notaris penerima protokol Notaris sebelum melakukan serah terima protokol Notaris adalah:

1. Menghubungi Ketua MPD untuk meminta persetujuan Beliau;

2. Menghubungi anggota MPD untuk sebagai saksi dalam proses serah terima protokol Notaris karena Ketua MPD berhalangan hadir;

\footnotetext{
${ }^{9}$ Wawancara dengan Anita Febe Holiana, selaku Notaris \& mantan Anggota Majelis Pengawas Daerah di Kabupaten Temanggung pada Kamis, 22 Oktober 2020.
} 
3. Mengecek setiap berkas yang terdaftar dalam berita acara;

4. Menyiapkan ruang penyimpanan.

Tidak adanya penunjukan Notaris penerima protokol oleh MPD terlihat bahwa MPD bertindak pasif. Di sisi lain MPD juga beberapa kali mengalami penolakan oleh Notaris yang ditunjuk untuk menerima protokol Notaris dengan alasan takut dikemudian hari menanggung akibat hukum yang timbul dan/atau tidak adanya ruang penyimpanan yang cukup. Dengan demikian dalam praktek yang terjadi di lapangan bahwa pelimpahan protokol Notaris adalah merupakan hal yang diterima secara suka rela oleh penerima protokol Notaris. Karena tidak adanya sanksi tegas apabila menolak untuk menerima protokol Notaris sehingga tidak ada kesadaran tanggungjawab oleh sesama rekan Notaris untuk saling menjaga protokol Notaris. Penyerahan protokol Notaris baik oleh Notaris yang meninggal dunia ataupun pensiun menjadi persoalan yang cukup serius mengingat protokol Notaris akan terus ada dan bertambah sepanjang masih adanya Notaris bahkan saat ini jumlah peminatnya terus meningkat.

\section{Penutup}

\section{Kesimpulan}

Perlindungan hukum terhadap protokol Notaris di Kabupaten Temanggung belum sepenuhnya berjalan sesuai dengan Pasal 16 huruf b UUJN. Dari 2 contoh kasus yang Penulis teliti, pada contoh kasus pertama masih ada protokol Notaris yang hilang jejaknya dikarenakan ulah ahli waris yang tidak kooperatif. Ahli waris tidak paham mengenai tanggungjawabnya atas dokumen milik Negara yang seharusnya dijaga dan dipertahankan keberadannya. Di sini ahli waris telah melakukan perbuatan melawan hukum yang mana harus diselidiki apa maksud dan alasan ahli waris tidak mau membuat berita acara serah terima protokol Notaris yang diterimanya. Pada contoh kasus yang kedua, protokol Notaris sampai ditangan yang tepat karena Notaris pemberi protokol Notaris sudah menyadari bahwa dirinya akan pensiun dari profesinya tersebut dan juga Notaris pemberi protokol Notaris menyadari pentingnya protokol Notaris sebagai arsip milik Negara yang harus dilindungi dan dilimpahkan kepada orang yang tepat.

Majelis Pengawas Daerah Kabupaten Temanggung sudah berperan aktif dalam melakukan pembinaan dan pengawasan kepada Notaris tetapi notaris penerima protokol notaris tidak dapat diajak bekerjasama sehingga peran Majelis Pengawas Daerah menjadi tidak optimal dikarenakan Majelis Pengawas Daerah tidak tegas kepada penerima protokol Notaris yang sudah berlarut-larut membuat berita acara penyerahan protokol Notaris dan sampai saat ini protokol notaris tersebut telah dianggap hilang oleh Majelis Pengawas Daerah.

\section{Saran}

Diperlukan penyempurnaan Undang-Undang Nomor 02 Tahun 2014 tentang Jabatan Notaris khususnya mengenai pelimpahan protokol Notaris. UUJN harus mengatur tentang siapa yang berhak menerima protokol Notaris, bagaimana kriteria Notaris yang bisa menerima protokol Notaris dan perlu adanya sanksi terhadap Notaris yang menolak menerima protokol Notaris. 


\section{Officium Notarium}

ISSN: $2776-5458$

Angie Athalia Kusuma. Perlindungan Hukum terhadap Protokol... 37

Majelis Pengawas Daerah harus rutin mensosialisasikan pentingnya protokol Notaris agar setiap individu yang berprofesi sebagai Notaris tidak menyepelekan penyimpanan protokol Notaris. Sosialisasi juga perlu dilakukan kepada keluarga dan staf Notaris sehingga apabila sewaktu-waktu Notaris meninggal dunia, keluarga atau ahli waris Notaris tersebut tidak kehilangan arah dan tahu apa yang harus dilakukan terhadap arsip milik negara tersebut.

\section{Daftar Pustaka}

\section{Buku}

Adjie Habib, Hukum Notaris Indonesia - Tafsir Tematik Terhadap Uu No. 30 Tahun 2004 Tentang Jabatan Notaris, Refika Aditama, Bandung, 2010.

Anshori Abdul Ghofur, Lembaga Kenotariatan Indonesia Perspektif Hukum Dan Etika, Uii Press, Yogyakarta, 2009.

Hartanti Sulihandri Dan Nisya Rifiani, Prinsip-Prinsip Dasar Profesi Notaris, Ctk. Kesatu, Dunia Cerdas, Jakarta, 2013.

Soegondo Notodisoerjo, Hukum Notariat Di Indonesia (Suatu Penjelasan), Ctk. Kedua, Raja Grafindo Persada, Jakarta, 1993.

Soesanto R., Tugas, Kewajiban Dan Hak-Hak Notaris, Wakil Notaris, Pradnya Paramita, Jakarta, 1982.

\section{Perundang-Undangan:}

Undang-Undang Nomor 02 Tahun 2014 tentang Jabatan Notaris.

\section{Lain-Lain}

Wawancara dengan Anita Febe Holiana, S.H., selaku Notaris \& mantan Anggota Majelis Pengawas Daerah di kabupaten Temanggung. 